\title{
WANITA DALAM ISLAM
}

\begin{abstract}
Zainul Muhibbin*
Abstrak

Emansipasi wanita dalam ajaran Islam selalu menjadi bahan diskusi yang menarik, karena ada anggapan bahwa ajaran Islam diskriminatif terhadap wanita. Benarkah Islam diskriminatif? Hal ini perlu diteliti dan dibuktikan. Dalam perspektif sejarah dapat dibuktikan bagaimana Islam telah mengangkat derajat wanita, ini dapat dilihat dengan mengkomparasikan kondisi wanita pra Islam dengan pasca Islam. Dari perspektif Syari'ah dapat dibuktikan bahwa hakikatnya tidak ada diskriminasi antara laki-laki dan wanita di hadapan hukum Islam. Perspektif Al-Qur'an juga membuktikan bahwa Allah selalu mendudukkan laki-laki dan wanita dalam posisi yang sama, tidak ada diskriminasi dalam Al-Qur'an. Berdasarkan tiga perspektif di atas, terbukti bahwa Islam telah mengangkat derajat kaum wanita, sehingga terjadi kesetaraan antara wanita dengan laki-laki. Dalam Islam ada bagian ajaran yang bersifat absolut dan ada yang bersifat relatif; yaitu yang merupakan ajaran-ajaran pokok (ushul) yang ada dalam Al-Qur'an dan As-Sunnah, dan yang merupakan hasil pemikiran manusia (ijtihad) tentang perincian dan penjabaran (furu') tentang cara pelaksanaan ajaran-ajaran pokok tersebut. Dalam berijtihad manusia sangat mungkin terpengaruh oleh budaya yang ada, termasuk yang masih patrilineal. Sementara itu teks-teks Al-Qur'an dan Hadts (ajaran pokok) telah menggariskan prinsip dan semangat kesetaraan jender, oleh karena itu perlu dilakukan reinterpretasi untuk menghasilkan pemahaman-pemahaman yang sesuai dengan prinsip dan semangat ajaran pokok Islam tersebut.
\end{abstract}

Kata kunci: emansipasi, sejarah, syari'ah, Al-Qur'an.

Isu emansipasi wanita atau kesetaraan jender sering digunakan oleh pihakpihak tertentu untuk memojokkan Islam. Secara umum dikatakan bahwa telah terjadi diskriminasi antara laki-laki dan wanita dalam ajaran Islam. Melihat ajaran Islam siapa pun harus cermat dan teliti dalam memahaminya. Untuk mengetahui ajaran Islam, orang harus mampu melihatnya secara benar terhadap bagian-bagian yang ada dalam ajaran Islam agar bisa memahaminya secara obyektif. Dalam Islam ada bagian-bagian yang bersifat absolut dan ada yang bersifat relatif. Yang absolut adalah bagian yang merupakan ajaran-ajaran pokok (ushul) yang ada dalam AlQur'an dan As-Sunnah. Sedangkan yang relatif adalah bagian ajaran yang merupakan hasil pemikiran manusia (ijtihad) tentang perincian dan penjabaran (furu') tentang cara pelaksanaan ajaran-ajaran pokok tersebut.

\footnotetext{
*Dosen UPM Soshum ITS
} 
Dalam konteks ini, bila Agama (Islam) dihadapkan dengan kebudayaan maka bisa memunculkan dua paradigma relasi, yaitu Agama mempengaruhi kebudayaan dan kebudayaan mempengaruhi Agama. Di sisi lain, sudah menjadi rahasia umum, bahwa budaya patriarki dan struktur patrilineal dalam sistem sosial terdapat di banyak bagian (daerah) dari seluruh jagad bumi ini, dan di zaman dahulu ini sama sekali tidak terkait dengan ajaran Islam. Oleh karena itu bila ada ajaran yang tampak patrilinear maka itu bisa dipahami sebagai kebudayaan yang mempengaruhi Agama.

Perlu dipahami bahwa jika dikatakan Agama mempengaruhi kebudayaan, maka yang dimaksud adalah Agama dalam arti ajaran-ajaran pokoknya (ushul), dan jaran-ajaran pokok inilah yang telah mempengaruhi kebudayaan umat manusia. Jika dikatakan kebudayaan mempengaruhi Agama, maka yang dimaksud adalah Agama dalam arti ajaran-ajaran yang bersifat ijtihadi tentang hal-hal yang tidak pokok (furu'). Dalam berijtihad sering kali manusia tidak bisa lepas dari latar belakang subyektivitasnya, misalnya keilmuan, kebudayaan di sekitarnya dan kondisi sosial lainnya.

Dalam Islam, prinsip persamaan (emansipasi) selalu dipegang erat karena Islam menghormati dan memuliakan manusia sebagaimana kapasitasnya sebagai manusia. Manusia dari keturunan manapun, ras atau warna kulit apapun tidak ada bedanya di mata Islam. Semua unsur kesukuan dan ras sama sekali tidak memjadi pertimbangan sebagai unsur pembeda. Demikian juga dengan masalah kaya dan miskin, penguasa dan rakyat jelata, serta laki-laki dan wanita, kecuali jika telah masuk ke wilayah persoalan biologis.

Permasalahan perbedaan antara laki-laki dan wanita sering disebut dengan istilah jender. Kata jender merupakan kosa kata yang terambil dari bahasa Inggris gender yang berarti jenis kelamin. Secara terminologis jender dimaknai sebagai "Interpretasi mental dan kultural terhadap perbedaan kelamin yakni laki-laki dan wanita. Jender biasanya dipergunakan untuk menunjukkan pembagian kerja yang dianggap tepat bagi laki-laki dan wanita". Bisa juga dikatakan, jender adalah suatu konsep yang digunakan untuk mengidentifikasi perbedaan laki-laki dan wanita dilihat dari segi sosial budaya. Oleh karena itu, berdasarkan terminologi tersebut 
maka jender merupakan permasalahan di luar aspek persoalan biologis. Pengertian ini harus menjadi patokan dalam setiap kajian dan penelitian tentang jender.

\section{Perspektif Sejarah}

Di dalam sejarah, sebagaimana telah diketahui secara umum, seperti apa budaya masyarakat Arab sebelum kedatangan Islam. Mereka memperlakukan wanita demikian rendah; wanita-wanita yang dinikahi seorang laki-laki, bila sang lelaki itu meninggal dunia, maka para wanita (istri) tersebut dapat diwarisi oleh anakanaknya. Bagaimana mungkin ada manusia (wanita) yang dianggap seperti barang yang dapat diwariskan. Demikian juga masyarakat Arab waktu itu, bila mendapati anaknya yang baru lahir ternyata laki-laki maka mereka sangat gembira dan bangga, tapi bila anaknya yang lahir itu ternyata perempuan maka mereka bersedih, kecewa, malu bahkan sampai tega membunuhnya atau menguburnya hidup-hidup. Bayi perempuan itu dianggapnya sebagai aib.

Budaya masyarakat yang diskriminatif terhadap wanita tersebut kemudian dihapus oleh Islam. Di antara ayat-ayat Al-Qur'an yang turun untuk mengikis habis sikap diskriminatif tersebut adalah:

"Dan janganlah kamu kawini wanita-wanita yang telah dikawini oleh ayahmu, terkecuali pada masa yang telah lampau. Sesungguhnya perbuatan itu amat keji dan dibenci Allah, dan seburuk-buruk jalan (yang ditempuh)." (Q.S. An-Nisa': 22)

"Dan apabila seseorang dari mereka diberi kabar dengan (kelahiran) anak perempuan, hitamlah (merah padamlah) mukanya, dan dia sangat marah. Ia menyembunyikan dirinya dari orang banyak, disebabkan buruknya berita yang disampaikan kepadanya. Apakah dia akan memeliharanya dengan menanggung kehinaan ataukah akan menguburkannya ke dalam tanah (hidup-hidup)? Ketahuilah, alangkah buruknya apa yang mereka tetapkan itu.” (Q.S. An-Nahl: 58-59)

Ayat-ayat di atas merupakan sebagian saja dari ayat-ayat yang diturunkan dalam rangka upaya menghilangkan budaya yang diskriminatif terhadap wanita dan laki-laki. Pada prinsipnya Islam menginginkan terwujudnya kesetaraan antara lakilaki dan wanita (jender).

Mengenai sejarah penciptaan wanita, memang ada sebuah hadits Nabi yang dinilai shahih, yang berbunyi: "Saling pesan-memesanlah untuk berbuat baik 
kepada wanita, karena mereka diciptakan dari tulang rusuk yang bengkok" (H.R. Al-Bukhari, Muslim dan Tirmidzi, dari Abu Hurairah). Hadits ini tidak bisa dipahami secara tekstual begitu saja, khususnya terhadap kata "tulang rusuk yang bengkok", dengan makna wanita diciptakan dari tulang rusuk Adam, yang kemudian mengesankan kerendahan derajat kemanusiaannya dibandingkan laki-laki, karena diciptakan dari tulang rusuk laki-laki yang bengkok.

Sebenarnya telah banyak ulama yang telah menjelaskan makna sesungguhnya dari hadits ini. Kata tulang rusuk yang bengkok harus dipahami secara majazi (kiasan), dalam pengertian bahwa hadits tersebut memperingatkan para lakilaki agar menghadapi wanita dengan bijaksana. Karena ada sifat, karakter dan kecenderungan wanita yang tidak sama dengan laki-laki. Bila ini tidak disadari maka bisa jadi kaum lelaki memaksakan kehendak dan sikapnya secara kaku tanpa melihat karakter dan sifat bawaan wanita, sehingga akibatnya akan fatal, sebagaimana fatalnya meluruskan tulang rusuk yang bengkok (Shihab, 1992: 271). Indikasi bahwa kata tulang rusuk yang bengkok tidak bisa dipahami secara tekstual adalah karena dikaitkannya tulang rusuk yang bengkok dengan masalah berpesan-memesan (taushiyah), sehingga harus dipahami secara majazi.

Dalam sejarah Islam sebenarnya banyak bukti dan contoh yang menunjukkan bahwa tidak ada sikap diskriminatif terhadap wanita dalam Islam, hanya saja ini tidak banyak diungkapkan oleh para sejarawan. Charis Waddy dalam bukunya Women in Muslim History mengatakan:

"Tak banyak kelompok lelaki dan wanita di dalam sejarah yang mengalami perubahan-perubahan yang demikian drastis dan banyak pengaruhnya dalam sejarah seperti orang-orang yang hidup di sekeliling (Nabi) Muhammad. Catatan-catatan mereka membuktikan adanya suatu pengertian akan tujuan, tentang adanya kesetiaan terhadap suatu tujuan yang menuntut segala-galanya dan yang membuat kekurangan apapun tidak berarti sama sekali." (Waddy, 1987: 33)

Nabi Muhammad memang tidak pernah bersikap diskriminatif terhadap kaum wanita. Umat Islam diperlakukan sama di hadapan Nabi, semua dihargai dan dihormati sebagai sahabatnya baik laki-laki maupun wanita. Merekapun berjuang bersama Nabi memperjuangkan tujuan Islam, menegakkan kalimah Allah, dalam posisi (derajat), hak dan kesempatan yang sama. Di hadapan umat Islam Nabi selalu 
bersikap egaliter, tidak lebih menghormati dan menghargai yang laki-laki daripada yang wanita, demikian juga sebaliknya, maka derajat wanita adalah sama dengan laki-laki. Aisyah, istri Nabi, saat bercadar ataupun sedang tidak bercadar, selalu berhasil memainkan peranan aktif dalam segala urusan sepanjang hidupnya. Dia merupakan tokoh dan potret wanita muslimah yang berkualitas, seperti juga Khadijah.

Dalam sebuah hadits diceritakan: Ada seorang wanita yang bermukim di sekitar masjid meninggal dunia. Suatu ketika Rasulullah menanyakannya, dan para sahabat menjawab: "Dia tetah wafat". Rasulullah bersabda: “ Mengapa kalin tidak memberitahuku?". Tampaknya para sahabat meremahkan hal itu . Kemudian Rasulullah bersabda: “Tunjukkan kepadaku di mana kuburannya”. Lalu para sahabat menunjukkannya, kemudian Rasulullah mensalatinya. (H.R. Muttafaq alaih). Jelas sekali tergambar bagaimana Nabi begitu menghargai wanita itu meskipun wanita tersebut bukanlah seorang yang terpandang, dia hanya anggota masyarakat biasa.

Dalam sejarah kekuasaan Islam pasca zaman Nabi, sebenarnya juga banyak contoh peranan wanita yang sangat penting dan menentukan. Sultanah Radiyah memegang kekuasaan di Delhi (India) pada tahun 634 H./1236 M., termasuk bagian dari kekuasaan Daulat Bani Abbasiyah. Dia meraih tahta berkat kekuatan militer bangsa Mamluk. Radiyah mewarisi tahta dari ayahnya, Sultan Iltutmisy. Dia memiliki dua gelar, yaitu Radiyah al-Dunya wa al-Din dan Balqis Jihan, namanya dicetak dalam mata uang dengan tulisan: "Pilar kaum wanita, Ratu segala zaman, Sultanah Radiyah binti Syams al-Din Iltutmisy” (Mernissi, 1994: 141).

Syajarat al-Durr menaiki tahta Mesir pada 648 H./1250 M. Mirip dengan Radiyah, Syajarat al-Durr memperoleh tahta dari suaminya, Malik al-Salih, penguasa Ayyubiyah terakhir. Dinasti Ayyubiyah adalah dinasti yang didirikan oleh Salahuddin Al-Ayyubi (Saladin), pahlawan perang salib yang terkenal. Meskipun masa kekuasaan Syajarat al-Durr tidak lama, namun rakyatnya sangat menghormatinya sebagai penguasa yang baik dan mumpuni. Di antara doa yang tercatat yang diucapkan kaum muslimin semasa pemerintahannya adalah: "Semoga Allah melindungi sang dermawan Ratu kaum muslimin yang diberkahi keduniaan 
dan keimanan, ibu dari Khalid al-Mu'tasimiyah, istri setia Sultan Malik al-Salih.” (Mernissi, 1994: 142).

Di Yaman, di antara sekian banyak kaum wanita yang memegang tampuk kekuasaan politik, ada dua orang, yaitu Malikah Asma dan Malikah Arwah, yang memiliki kriteria istimewa sebagai kepala negara. Tidak jarang khutbah di masjidmasjid menyebut namanya. Ini merupakan penghargaan dan penghormatan yang sulit dicari bandingannya di negeri Arab manapun setelah kedatangan Islam. Asma binti Syihab al-Sulaihiyah (wafat 480 H./1087 M.) memerintah Yaman dengan baik, bijaksana dan mengagumkan. Arwah binti Ahmad al-Sulaihiyah yang juga mendapatkan kriteria mutlak sebagai kepala negara. Ia adalah menantu Asma, istri putranya yang bernama Al-Mukarram. Arwah memegang tampuk kekuasaan hampir setengah abad lamanya (485-532 H./1091-1138 M.). Kedua ratu ini mendapat gelar kehormatan sama yaitu As-Sayyidah Al-Hurrah (Putri bangsawan yang bebas dan merdeka atau wanita penguasa yang tidak tunduk kepada kekuatan manapun). (Mernissi, 1994: 179-180).

Fakta adanya wanita-wanita penguasa tersebut membuktikan bahwa Islam tidak membedakan derajat wanita dan laki-laki. Inilah kesetaraan dalam Islam. Bila ada anggapan-anggapan atau sikap yang terkesan membedakan kaum laki-laki dan wanita, itu merupakan pengaruh budaya yang masih patrilineal terhadap masyarakat muslim.

\section{Perspektif Syari’ah (Hukum)}

Syari'ah Islam telah menetapkan prinsip emansipasi baik secara teoritis maupun praksis (operasional). Syari'ah memperlakukan semua manusia dalam posisi yang sama, baik laki-laki, wanita, kaya, miskin, tua, muda dan seterusnya. Hukum halal adalah halal bagi semua kalangan, yang haram adalah haram untuk semua kalangan. Hukum wajib, sunnah, mubah dan sebagainya juga untuk semua lapisan umat. Demikian juga suatu sanksi hukum harus diberlakukan dan ditegakkan untuk semua kalangan.

Al-Qur'an menegaskan bahwa kewajiban dan hak wanita untuk beribadah dan hidup beragama serta masuk surga adalah sama dengan laki-laki. Penegasan ini bertujuan menghapus opini sebelumnya yang bersumber dari berbagai kepercayaan 
atau agama yang percaya bahwa hidup beragama dan masuk surga adalah monopoli laki-laki. Islam telah mengangkat wanita sederajat dengan laki-laki baik dalam martabat kemanusiaan (sosial) maupun harkat keberagamaan. Ajaran Islam mengakui hak-hak sipil yang penuh bagi wanita, ini merupakan suatu kebanggaan bagi wanita muslimah yang tahu bahwa Agamanya telah memberikannya hak, yang oleh dunia barat baru tiga belas abad kemudian hak yang seperti itu diakui setelah kaum wanitanya berjuang keras menuntut emansipasi (Yafie, 1994: 265). Sementara dalam Islam hak-hak wanita ditegakkan dan dilindungi tanpa menunggu adanya tuntutan emansipasi dari kaum wanita.

Dalam Islam, wanita juga diangkat derajatnya di hadapan hukum, sehingga secara prinsip laki-laki dan wanita sama di hadapan hukum. Dalam masalah persaksian, Al-Qur'an menegaskan berlakunya persaksian wanita, misalnya dalam firman Allah:

"Dan mintalah persaksian dua orang saksi dari para lelaki kalian. Jika tidak ada dua orang lelaki, maka boleh seorang lelaki dan dua orang wanita untuk saksi-saksi yang kalian ridlai, agar bila yang seseorang lupa maka yang lain dapat mengingatkan." (Q.S. Al-Baqarah: 282).

Yang perlu dipahami dari ayat di atas adalah; Pertama, wanita sebelum itu tidak mempunyai hak ini dan tidak diperhitungkan kehadirannya sebagai saksi di depan pengadilan, kemudian oleh Islam dirubah dengan diakuinya sebagai saksi dan dipertegas keabsahannya. Kedua, adanya angka satu laki-laki dan dua wanita itu harus dipahami secara benar sesuai dengan konteksnya. Kepasifan wanita dalam banyak segi kehidupan dibanding laki-laki, pada masa itu, menjadikannya lebih sedikit disebut-sebut daripada laki-laki. Hal yang memerlukan kerja otak dan kecermatan perhitungan memerlukan intelektualitas yang cukup memadai. Ketika itu wanita tidak mendapatkan kesempatan memperoleh pendidikan yang memadai. Islam benar-benar memperhatikan kelemahan ini dalam diri wanita (Al-Haddad, 1992: 12). Ditambah lagi, secara psikologis, kebanyakan wanita kondisi stabilitas emosionalnya tidak sestabil laki-laki. Oleh karena itu, bila perkembangan zaman telah mewujudkan peningkatan kualitas wanita maka pertimbangan intelektualitas itu pun harus diperhatikan sesuai realita perkembangan yang ada. Di sisi lain Islam 
telah mewajibkan menuntut ilmu bagi laki-laki dan wanita tanpa ada perbedaan sedikitpun.

Dalam masalah warisan, di zaman pra Islam wanita menjadi barang warisan bagi lelaki pemiliknya (suami). Ia dapat diwariskan begitu saja kepada saudara dan putra sang suami bila meninggal dunia. Sekarang semua itu telah dihapus oleh Islam, dan dapat dilihat bagaimana Islam telah mengangkat derajat wanita, mengeluarkannya dari posisi yang mirip budak menjadi sejajar dengan lakilaki dalam menerima bagian warisan. Dari barang warisan menjadi penerima warisan, atau memiliki hak waris, ini sungguh luar biasa.

Mengenai poligami, sebagaimana kita ketahui, poligami merupakan satu diantara sejumlah tradisi bangsa Arab pra Islam yang sangat kental dan kuat, yang dikikis oleh Islam secara halus dan bijaksana. Para lelaki Arab waktu itu senang sekali melakukan poligami, dan poligami dalam tradisi mereka adalah tanpa batas dan aturan. Ini sangat terkait dengan pandangan mereka terhadap wanita. Kemudian datang Islam yang mula-mula meletakkan batas maksimal bagi tindakan poligami, dan selanjutnya menetapkan syarat harus adil. Jika ada rasa ketakutan untuk tidak bisa adil, maka Allah memerintahkan satu istri saja. Apabila kita cermati ketentuan poligami tersebut maka jelas sekali bahwa semangat Al-Qur'an dalam masalah ini adalah monogami. Apalagi bila ditambah dengan penegasan ayat Al-Qur'an: “Dan kamu sekali-sekali tidak akan mampu berlaku adil diantara istri-istrimu, walaupun kamu sangat ingin berlaku demikian” (Q.S. An-Nisa': 129).

Kemudian dalam masalah politik, sebenarnya Islam tidak pernah membetasi hak politik hanya milik laki-laki, sementara wanita tidak memiliki hak ini. Pendapat yang mengatakan bahwa hak kepemimpinan hanya pada laki-laki lebih banyak dipengaruhi oleh latar belakang kondisi sosial-politik, adat istiadat, serta kecenderungan masing-masing individu (subyektif) sehingga kemudian mempengaruhi cara pandang dan pemahaman mereka terhadap teks Al-Qur'an dan hadits.

M. Quraish Shihab berpendapat:

"Tidak mustahil, jika para pakar terdahulu hidup bersama para putra-putri abad ke duapuluh, dan mengalami apa yang kita alami, serta mengetahui perkembangan masyarakat dan IPTEK, mereka pun akan memahami ayat- 
ayat Al-Qur'an sebagaimana pemahaman generasi masa kini. Sebaliknya, seandainya kita berada di kurun waktu saat mereka hidup, tidak mustahil kita berpendapat seperti mereka. Ini berarti bahwa seluruh pendapat yang dikemukakan, baik dari para pendahulu maupun pakar yang akan datang, semuanya bermuara pada teks-teks keagamaan.” (Shihab,1996: 318)

Menurut Andree Feillard, masih banyak masyarakat yang menutup mata dan mencoba mengingkari kelebihan yang dianugerahkan Allah kepada wanita. Pengaruh kultur yang bersifat patrilineal memang telah mengurangi dan menafikan prinsip memuliakan wanita. Oleh karena itu di tengah arus perubahan yang menggejala di berbagai belahan dunia, umat Islam perlu meninjau dan mengkaji kembali anggapan-anggapan yang merendahkan wanita dan kembali kepada prinsipprinsip Islam yang memuliakan wanita. Laki-laki dan wanita harus sama-sama melaksanakan tanggungjawab bersama dan saling mendukung satu sama lain. Dalam konteks peran politik, wanita diperbolehkan, jika memang mampu. Dengan kata lain kedudukan wanita dalam sistem negara bangsa (nation state) telah terbuka lebar dengan tetap mengingat bahwa kualitas tetap menjadi ukuran, sebagaimana juga kaum laki-laki. (Feillard, 1999: 224-225).

\section{Perspektif Al Qur'an}

Dalam Al-Qur'an telah ditegaskan, bahwa Allah menciptakan manusia adalah untuk beribadah kepadaNya. Dalam hal ini maka manusia disebut Abdullah (hamba Allah). Manusia dalam kapasitasnya sebagai hamba, tidak ada perbedaan antara laki-laki dan wanita, keduanya berpotensi dan mempunyai peluang yang sama untuk menjadi hamba ideal (muttaqin). Untuk mencapai derajat muttaqin Al-Qur'an tidak pernah membedakan jenis kelamin, suku bangsa atau kelompok etnis. Hamba Allah baik laki-laki maupun wanita masing-masing akan mendapatkan penghargaan dari Allah sesuai dengan kadar pengabdiannya, bukan dari jenis kelaminnya. Kalaupun ada permasalahan-permasalahan yang memberikan kekhususan tertentu bagi laki-laki, itu pun tidak menjadikan laki-laki lebih utama (mulia) di hadapan Allah. Kekhususan tersebut diberikan dalam kapasitas laki-laki sebagai kepala rumah tangga dan anggota masyarakat yang memiliki peran publik dan sosial yang lebih ketika ayat Al-Qur'an diturunkan (Umar, 1999: 248-249). Yang menjadi pertimbangan sama sekali bukan karena laki-laki atau wanita. 
Disamping manusia sebagai Abdullah, manusia juga sekaligus sebagai Khalifatullah fil ardl (khalifah Allah di bumi). Kata Khalifah dalam Al-Qur'an tidak menunjuk kepada salah satu jenis kelamin, bangsa atau kelompok etnis tertentu. Laki-laki dan wanita mempunyai fungsi dan peran yang sama dalam kapasitasnya sebagai khalifah Allah. Mereka akan mempertanggungjawabkan tugas-tugas kekhalifahannya di bumi dalam posisi yang sama di hadapan Allah (Umar, 1999: 252-253). Pada prinsipnya tugas dan tanggungjawab manusia sebagai khalifah Allah itu adalah menciptakan kemakmuran (maslahat) dan menjaga serta melestarikan kemakmuran alam.

Berikutnya Al-Qur'an membuka peluang yang sama bagi laki-laki dan wanita untuk meraih prestasi dari usaha yang dilakukan dalam berbagai segi kehidupan. Allah dalam firmanNya menegaskan:

"Barang siapa yang mengerjakan amal salih, baik laki-laki maupun perempuan dalam keadaan beriman, maka sesungguhnya akan Kami berikan kepadanya kehidupan yang baik dan sesungguhnya akan Kami beri balasan kepada mereka dengan pahala yang lebih baik dari apa yang telah mereka kerjakan.” (Q.S. An-Nahl: 97)

"Sesungguhnya laki-laki dan perempuan yang muslim, laki-laki dan perempuan yang mukmin, laki-laki dan perempuan yang tetap dalam ketaatannya, laki-laki dan perempuan yang benar, laki-laki dan perempuan yang sabar, laki-laki dan perempuan yang khusyu', laki-laki dan perempuan yang bersedekah, laki-laki dan perempuan yang berpuasa, lakilaki dan perempuan yang memelihara kehormatannya, laki-laki dan perempuan yang banyak menyebut (nama) Allah, Allah telah menyediakan untuk mereka ampunan dan pahala yang besar.” (Q.S. Al-Ahzab: 35)

Ayat di atas merupakan beberapa ayat dari sekian banyak ayat yang berbicara dalam topik yang sama. Ayat tersebut memberi pelajaran tentang konsep kesetaraan jender dan memberikan ketegasan bahwa suatu prestasi, baik dalam masalah spiritual (ukhrawi) maupun urusan karir profesional (duniawi), tidak mesti dimonopoli oleh salah satu jenis kelamin. Laki-laki dan wanita memperoleh kesempatan yang sama dalam meraih prestasi optimal. Hanya saja karena pengaruh budaya yang begitu kuat, maka konsep ideal Al-Qur'an ini niscaya membutuhkan proses pemahaman dan sosialisasi serius di tengah masyarakat untuk menumbuhkan kesadaran. 
Melihat, setidaknya beberapa aspek pembicaraan Al-Qur'an di atas, dapat kita pahami lebih lanjut bahwa Al-Qur'an telah mencanangkan prinsip-prinsip kesetaraan jender. Tidak ada perbedaan derajat antara laki-laki dan wanita dalam hal apapun, termasuk dalam kehidupan suami istri. Ikatan erat antara laki-laki dan istrinya didefinisikan secara jelas dalam Al-Qur'an dengan redaksi kesetaraan: “Wanita-wanita (para istri) itu adalah pakaian bagimu sebagaimana kamu semиa adalah pakaian bagi mereka” (Q.S. Al-Baqarah: 187). Hanya sayangnya ayat ini sering ditafsirkan secara dangkal, yaitu sebatas hubungan suami istri secara fisik, padahal ayat ini bisa bermakna lebih dalam dan penting. Dalam tradisi keagamaan di seluruh dunia, pakaian seseorang merupakan alter-egonya, yaitu obyek yang paling erat terkait dengan kepribadiannya (Schimmel, 1998: 93). Oleh karena itu kandungan makna ayat ini termasuk mencakup aspek psikologis dan filosofi kesetaraan. Segala kelebihan dan kekurangan yang dimiliki masing-masing individu suami istri harus bisa saling dipahami, sehingga terbentuk sikap saling memberi dan menerima dalam posisi yang setara.

\section{Kesimpulan}

Dari pemaparan di atas dapat disimpulkan bahwa ajaran Islam, setidaknya berdasarkan tiga perspektif di atas, terbukti telah mengangkat derajat kaum wanita, sehingga terjadi kesetaraan antara kaum wanita dengan laki-laki. Pada prinsipnya ajaran Islam selalu menganggap sama antara laki-laki dan wanita dalam berbagai hal. Ketika kita bicara ajaran Islam maka yang harus dicermati adalah, di satu sisi ada Al-Qur'an dan Hadits yang berupa teks-teks dasar, dan di sisi lain ada pemahaman (fiqh) dan tafsir yang merupakan hasil kerja intelektual (ijtihad) dalam memahami teks-teks dasar. Teks Al-Qur'an dan Hadits adalah dalil final yang tidak bisa dirubah, akan tetapi hasil pemahaman terhadap teks tidak bisa dikatakan final, oleh karena itu masih terbuka lebar untuk dilakukan reinterpretasi.

Hasil ijtihad yang merupakan karya kerja intelektual manusia itu sangat mungkin terpengaruh oleh budaya yang ada, termasuk budaya yang masih patrilineal. Sementara itu teks-teks dasar (ajaran pokok) telah menggariskan prinsip dan semangat kesetaraan jender, namun beberapa hasil ijtihad masih mengandung pemahaman-pemahaman yang terkesan diskriminatif terhadap wanita. Oleh karena 
itu perlu dilakukan reinterpretasi untuk menghasilkan pemahaman-pemahaman yang sesuai dengan prinsip dan semangat ajaran pokok Islam tersebut.

\section{Daftar Pustaka}

Al-Haddad, At-Tahir, 1992, Wanita dalam Syari'at dan Masyarakat, ter. M. Adib Basri, Pustaka Firdaus, Jakarta.

Al-Qardawi, Yusuf, 1995, Karakteristik Islam Kajian Analitik, ter. Rafi' Munawwar dan Tajuddin, Risalah Gusti, Surabaya.

As-Shan'ani, Al-Imam Muhammad bin Ismail, 1991, Subul As-Salam, vol. 2, Dar alFikr, Beirut.

Feillard, Andree, 1999, "Potensi Perubahan Relasi Gender di Lingkungan Umat Islam, Sebuah Proyeksi dan Pemaparan Data", dalam Syafiq Hasyim (ed), Menakar "Harga" Perempuan Eksplorasi Lanjut atas Hak-hak Reproduksi Perempuan dalam Islam, Mizan, Bandung.

Mernissi, Fatimah, 1994, Ratu-ratu Islam yang Terlupakan, ter. Rahmani Astuti dan Enna Hadi, Mizan, Bandung.

Nasution, Harun, 1995, Islam Rasional Gagasan dan Pemikiran, Mizan, Bandung.

Schimmel, Annemarie, 1998, Jiwaku adalah Wanita Aspek Feminin dalam Spiritualitas Islam, ter. Rahmani Astuti, Mizan, Bandung.

Shihab, M. Quraish, 1992, Membumikan Al-Qur'an Fungsi dan Peran Wahyu dalam Kehidupan Bermasyarakat, Mizan, Bandung.

----------, 1996, Wawasan Al-Qur'an Tafsir Maudhu'i atas Pelbagai Persoalan Umat, Mizan, Bandung.

Umar, Nasaruddin, 1999, Argumen Kesetaraan Jender Perspektif Al-Qur'an, Paramadina, Jakarta.

Waddy, Charis, 1987, Wanita dalam Sejarah Islam, ter. Faruk Zabidi, Pustaka Jaya, Jakarta.

Yafie, Ali, 1994, Menggagas Fiqh Sosial dari Soal Lingkungan Hidup, Asuransi hingga Ukhuwah, Mizan, Bandung. 